\title{
Analisis Pendapatan Petani Padi Sawah \\ Di Kecamatan Sei Rampah, Kotarih,Sei Bamban \& Perbaungan Kabupaten Serdang Bedagai
}

\author{
Eliakim Purba \\ Dosen Tetap Fakultas Pertanian Universitas Amir Hamzah Medan
}

\begin{abstract}
Penelitian ini dilaksankan pada bulan Mei - juli 2019, Pelaksanaan Penelitian ini bertujuan untuk mengetahui besaran pendapatan Petani dalam usaha tani padi sawah di Kabupaten Serdang Bedagai. Hasil Penelitian ini menunjukkan bahwa rata rata luas lahan petani responden adalah $0.308 \mathrm{Ha}$, maka rata rata biaya produksi berupa saprodi pertanian yang harus dikeluarkan petani adalah Rp. 466.000, rata rata biaya tenaga kerja sebesar Rp. 2.283.000 dan rata rata penerimaan adalah $\mathrm{Rp}$. 7.646.000. Rata rata penerimaan yang diperoleh petani padi sawah di wilayah pertanian sebesar Rp. 5.097.000 dan biaya produksi dan tenaga kerja sebesar Rp. 2.749.0000, maka R/C ratio diperoleh sebesar 1,8. Artinya akan nmenghasilkan keuntungan sebesar 1.8. Karena nilai R/C Ratio lebih besar dari pada 1 $(\mathrm{R} / \mathrm{C}>1)$ maka usaha tani padi sawah layak untuk diusahakan.

Petani Responden pada usaha tani padi sawah minimal harus mampu meningkatkan produksi mencapai $2.233 \mathrm{Kg}$ per musim tanam dengan rata rata luas lahan dengan dengan luas lahan $0.038 \mathrm{Ha}$ agar tidak merugi. Sedangkan pendapatan minimal yang harus diperoleh berdasarkan perhitungan titik impas yaitu sebesar Rp. 3.167.000 per musim tanam.
\end{abstract}

Keyword : Biaya Usaha tani, penerimaan, Keuntungan Usaha Tani

\section{PENDAHULUAN}

Pembangunan Pertanian penting dalam memaksimalkan pemanfaatan geografi dan kekayaaan alam Indonesia, memadukannya dengan teknologi agar mampu memperoleh hasil sesuai dengan yang diharapkan. Sektor Pertanian bereperan penting dalam menyediakan bahan pangan bagi seluruh penduduk maupun menyediakan bahan baku bagi industry, dan untuk perdagangan ekspor (Wisma, 2012). Hal ini diawali dengan meningkatkan kualitas sumberdaya manusia yang baik, dimana setiap individu dalam rumah tangga mendapatkan asupan pangan dalam jumlah yang cukup, aman dan bergizi secara bekelanjutan yang pada gilirannya akan meningkaytkan status kesehatan dan memberikan kesempatan agar setiap individu mencapai potensi maksimumnya. Dengan demikian ketahanan pangan merupakan komponen yang tidak dapat terpisahkan dari ketahanan pangan nasional, dimana ketahanan pangan nasional berakitan dengan kualitas sumber daya manusia.

Indonesia Pernah menjadi swasembada beras, disbabkan anatar alain oleh dukungan pemerintah yang memperioritaskan pembangunan pertanian disertai kebijakan ekonomi makro yang mendukung, terobosan teknologi baru (Revolusi Hijau) budidaya pado sawah dan kebijakan intensifikasi pertanian (BIMAS) yang mengatur penerapan teknologi secara sentralistik. Namun swasembada beras hanya dapat dipertahankan sampai tahun 1993. Intensifikasi melalui program BIMAS akhirnya berakhir, karena meningkkatnya kerusakan 
lingkungan disertai resistensi hama terhadap pestisida yang disebabkan konsumsi pestisida dan pupuk kimia yang mengikat (Badan Litbang, 2006)

Sebagai salah satu pilar ekonomi Negara, sektor pertanian dharapkan dapat meningkatkan pendapat terutama penduduk pedesaaan yang masih dibawah garis kemiskinan. Untuk itu berbagai investasi dan kebijakan telah dilakukan pemerintah untuk mendorong pertumbuhan di sektor pertanian. Investasi disektor pertanian seringkali sangat mahal, ditambah lagi tingkat pengambaliannya sangat rendah dan waktu investasinya juga panjang, sehingga tidak terlalu menarik bagi pihak swasta. Oleh sebab itu pembangunan irigasi, penyuluhan pertanian dan berbagai bentuk investasi dalam bentuk subsidi dan lainnya pada umumnya harus dilakukan pemerintah.

Sebagian besar petani padi merupakan masyarakat miskin atau berpendapatan rendah, rata rata pendapatan rumah tangga petani yakni hany sekitar 30\% dari tota pendapatan keluarga. Selain berhadapan dengan rendahnya pendapatan yang diterima petani, sector pertanian juga dihadapkan pada penurunan produksi dab produktivitas padi di lahan lahan sawah yang telah bertahun tahun diberi pupuk input yang tinggi tanpa mempertimbnagkan status kesuburan lahan dan pemebrian pupuk organic (Hasrimi Moetaqien, 2012).

Alternatif yang diperlukan untuk memecahkan masalah tersebut adalah program peningkatan produktivitas padi, melalui perbaikan kondisi fisik kima tanah dengan memberikan bahan organik dan perluasan areal. Departemen Pertanian pada tahun 2007 telah menghasilkan teknologi atau motivasi baru melalui pendekatan program Peningkatan Produksi Beras Nasional (P2BN) untuk memacu peningkatan produktivitas usaha tani padi dan peningkatan pendapatan petani. Penggunaan input produksi haruslah efesien, khususnya pada pertanaman padi.

Kecamatan Sei Rampah merupakan saah satu Kecamatan yang berada dalam Kabupaten Serdang Bedagai dan merupakan salah satu daerah yang sangat berpotensi dalam swasembada pangan. Berdsarkan sumber BPS Serdang Bedagai, BP3K Sei Rampah luas lahan padi sawah di Kecamatan tersebut mencapai $1.780 \mathrm{Ha}$ dan hampir sebagaian besar pendiuduk di Kecamatan Sei Rampah bermata pencaharian sebagai petani. Luas lahan usaha belum tentu menjamin kesejahteraan dan peningkatan pendapatan masyarakat di wilayah tersebut.

\subsection{Indentifikasi Masalah}

Berdasarkan urutan atar belakang diatas dapat dirumuskan masalah dalam penelitian ini adalah :

1. Berapa besaran pendapatan petani dalam usaha tani padi sawah di Kabpaten Serdang Bedagai

2. Apakah usaha tani padi sawah di Kabupaten serdang bedagai ayak untuk diusahakan

3. Berapa besaran BEP (Break Event Point) usaha tani padi sawah di Kab. Serdang Bedagai.

\subsection{Tujuan Penelitian}

Tujuan penelitian ini adalah :

1. Mengetahui besaran pendapatan petani dalam usaha tani padi sawah di Kabupaten Serdang Bedagai

2. Mengetahui kelayakan usaha tani padi sawah di Kab. Serdang Bedagai

3. Mengetahui Break Event Point usaha tani padi sawah di Kabupaten Serdang Bedagai. 


\section{LANDASAN TEORI}

Petani tradisional umumnya menanam padi hanya berdasarkan pengalaman, karena pengetahuan yang terbatasmaka satu jenis padi ditanam terus menerus dalam suatu lahan. Pola tanam yang demikian bukan cara yang baik,a terutama terhadap kemungkinan besar hama dan penyaki. Adapun jenis padi yang diusahakan petani adalah :

1. Padi sawah, yaitu padi yang ditanam disawah, yaitu lahan yang cukup memperoleh air. Padi sawah pada waktu tertentu memerlukan genangan air, termasuk sejak musim tanam sampai mulai berbuah.

2. Padi kering yaitu jenis padi yang tidak membutuhkan banyak air sebagaimana padi sawah. Bahkan padi kering ini dapat tumbuh hanya mengandalkan curah hujan (Rosyidi, 1998).

Usaha tani merupakan seluruh proses pengorganisasian faktor faktor produksi yaitu alam, tenaga kerja, modal dan pengelolaan yang diusahakan oelh perorangan atau sekumpulan orang untuk menghasilkan output yang dapat memenuhi kebutuhan keluarga ataupun orang lain disamping bermotif mencari keuntungan . Pada umumnya ciri ciri usaha tani di Indonesia adalah berlahan sempit, modal relative kecil, pengetahuan petani terbatas, kurang dinamik sehingga berakibat pada rendahnya pendapatan usaha tani (Rhardjo, P. 2001).

Biaya adalah semua pengeluaran yang dinyatakan dengan uang yang diperlukan untuk menghasilkan sesuatu produk dalam usaha periode produksi. Nilai biaya dinyatakan dengan uang, yang termasuk dengan biaya dalah : Sarana Produksi yang habis dipakai, seperti bibit, pupuk, pestisida, bahan bakar, bunga modal,d alam penanaman lain.

Menurut Carter dan Usry, 2009, Biaya dalah suatu nilai tukar, pengeluaran atau pengorbanan yang dilakukan untuk menjamin perolehan manfaat.

\subsection{Penerimaan Usaha Tani}

Penerimaan usaha tani adalah perkalian antar jumlah produksi yang diperoleh dengan harga produksi. Pendapatan usaha tani adalah selisih antara penerimaan dan seluruh biaya yang dikeluarkan dalam sekali periode. Pendapatan usaha tani merupakan selisih antara penerimaan dengan semua biaya. Pendapatan usaha tani merupakan slisih biaya yang dikeluarkan dan penemerimaan yang diperoleh Kotler, 1997). Besarnya pendapatan yang diterima merupakan balas jasa untuk tenaga kerja, modal kerja keluarga yang dipakai dan pengelolaan yang dilakukan oleh seluruh angota keluarga. Bentuk dan jumlah pendapatan memiliki fungsi yang sama, yaitu untuk memenuhi keperluan sehari hari dan memebrikan kepuasan petani agar dapat melanjutkan kegiatannya.

Keuntungan atau laba menunjukkan nilai tambajh (hasil) yang diperoleh dari modal yang dijalankan. Setiap kegiatan yang dijalankan perusahaan tentu berdasar modal yang dijalankan. Dengan modal itulah keuntungan atau laba diperoleh. Hal inilah yang menjadi tujuan utama dari setiap perusahaan (Muhmmad, 1995).

\subsection{Metode Penelitian.}

Penelitian ini dilaksanakan di bulan Mei -Juli 2019. Lokasi Penelitian di Kecamatan Sei Rampah Kabupaten Serdang Bedagai. Berdasarkan data dari BP3K Sei Rampah tahun 2014, sentra padi dengan luasan penanaman di wilayah kerja BP3K Serdang Bedagai terdapat empat wilayah, yaitu Sei Rampah, Perbaungan, Kotarih dan Sei Bamban daerah ini merupakan Sentara tanaman padi bagi Kabupaten Serdang Bedagai.

Jurnal Insitusi Politeknik Ganesha Medan 


\subsection{Populasi dan Sampel}

Populasi dalam penelitian ini adalah petani yang mengusahakan padi sawah yang terbagi dari 4 Gampong dengan jumlah petani 74 jiwa.

Pengambilan data sampel dilakukan dengan secara sederhana sebanyak 50\% dari jumlah populasi sudah memenuhi standar penelitian. Jumlah sampel sebanyak 37 orang . Jumlah dan sampel dapat dilihat pada table berikut ini.

\begin{tabular}{|c|c|c|c|}
\hline No & Desa Sampel & $\begin{array}{l}\text { Jumlah } \\
\text { (Orang) }\end{array}$ & $\begin{array}{l}\text { Jumlah } \\
\text { (orang) }\end{array}$ \\
\hline 1 & Sei Rampah & 16 & 8 \\
\hline 2 & Perbaungan & 34 & 17 \\
\hline 3 & Kotarih & 14 & 7 \\
\hline 4 & Sei Bamban & 10 & 5 \\
\hline \multicolumn{2}{|c|}{ Jumlah } & 74 & 37 \\
\hline
\end{tabular}

Sumber : Data Primer diolah, 32019

\section{METODE PENELITIAN}

\subsection{Lokasi Penelitian}

Penelitian ini dilaksanakan di bulan Mei -Juli 2019. Lokasi Penelitian di Kecamatan Sei Rampah Kabupaten Serdang Bedagai. Berdasarkan data dari BP3K Sei Rampah tahun 2014, sentra padi dengan luasan penanaman di wilayah kerja BP3K Serdang Bedagai terdapat empat wilayah, yaitu Sei Rampah, Perbaungan, Kotarih dan Sei Bamban daerah ini merupakan Sentara tanaman padi bagi Kabupaten Serdang Bedagai.

\subsection{Populasi dan Sampel}

Populasi dalam penelitian ini adalah petani yang mengusahakan padi sawah yang terbagi dari 4 Gampong dengan jumlah petani 74 jiwa.

Pengambilan data sampel dilakukan dengan secara sederhana sebanyak 50\% dari jumlah populasi sudah memenuhi standar penelitian. Jumlah sampel sebanyak 37 orang . Jumlah dan sampel dapat dilihat pada table berikut ini.

\begin{tabular}{|l|l|l|l|}
\hline No & $\begin{array}{l}\text { Desa } \\
\text { Sampel }\end{array}$ & $\begin{array}{l}\text { Jumlah } \\
\text { Populasi } \\
\text { (Orang) }\end{array}$ & $\begin{array}{l}\text { Jumlah } \\
\text { Sampel } \\
\text { (orang) }\end{array}$ \\
\hline 1 & Sei Rampah & 16 & 8 \\
\hline 2 & Perbaungan & 34 & 17 \\
\hline 3 & Kotarih & 14 & 7 \\
\hline 4 & Sei Bamban & 10 & 5 \\
\hline Jumlah & 74 & 37 \\
\hline
\end{tabular}

Sumber : Data Primer diolah, 32019

\subsection{Metode Pengolahan Data}


Pengumpulan data padi sawah menggunakan teknik observasi atau pengamatan langsung dengan melakukan pencatatan secara sistematis terhadap fenomena fenomena yang diselidiki dan wawancara secara langsung dengan narasumber yang mengetahui tentang objek yang diteliti. Data yang diperoleh disusun dalam bentuk tabulasi pengaolahan data.

\section{HASIL DAN PEMBAHASAN}

Petani responden dalam penelitian ini adalah yang beusahatani padai sawah yang ada di 4 daerah objek penelitian yakni desa Sei Rampah, Kotarih, Perbaungan dan Sei Bamban.

\section{IV.1. Karakteristik Petani Padi Sawah menurut sampel di Kecamatan Sei Rampah.}

\begin{tabular}{|l|l|l|}
\hline No & Karakteristik & Rata rata \\
\hline 1. & Umur (th) & 43 \\
\hline 2. & Pendidikan (th) & 8 \\
\hline 3. & Pengalaman (th) & 19 \\
\hline 4. & Jumlah Tanggungan (jiwa) & 5 \\
\hline 5 & Luas Lahan (Ha) & 0.308 \\
\hline
\end{tabular}

Berdasarkan table diatas diketahui bahwa rata rata umur petani padi sawah adalah 43 tahun. Umur petani akan mempengaruhi kemampuan fisik dan berfikir. Petani yang berumur lebih muda dan sehat biasanya mempunyai kemampuan fisik yang lebih kuat serta cepat dalam mengadopsi inovasi baru dari pada petani yang berumur tua.

Tingkat pendidikan merupakan factor yang dapat mempengaruhi tingkat keberhasilan kerja seseorang dan merupakan factor penunjang didalam penyerapan teknologi oleh petani.

Jumlah tanggungan keluarga juga akan mempengaruhi pendapatan dan pengeluaran keluarga petani. Semakin banyak jumlah tanggungan akan menjadi beban bagi petani bila ditinjau dari segi konsumsi. Namun jumlah keluarga juga merupakan asat yang penting dalam membantu kegaiatan petani karena akan menambah pencurahan tenaga kerja keluarga, sehingga biaya produksi yang harus dikeluarkan oleh petani akan lebih kecil.

Bila ditinjau dari luas lahan padi sawah wilayah penelitian maka sangat berpotensi untuk berswasembada pangan terutama di Kabupaten Serdang Bedagai. Namun hal ini sangat sulit terjadi tanpa ada campur tangan lembaga pemerintahan terkait seperti Dinas Pertanian dan Balai Penyuluhan Pertanian Perikanan dan Kehutanan (BP3K) selaku lembaga pemerintahan yang berperan untuk meningkatkan pengetahuan sikap ketrampilan para petani.

\section{IV.2. Luas Lahan Sawah di Wilayah Penelitian.}

Luas lahan juga akan mempengaruhi pendapatan petani padi sawah. Luas lahan merupakan factor produksi penting dalam usaha meningkatkan produksi yang dapat mempengaruhi pendapatan dan keuntungan yang diterima oleh petani. Berdasarkan hasil observasi di Sei Bamban, Kotarih, Perbaungan dan Sei Rampah, satu orang petani sampel memiliki 4 sampai dengan 12 petak sawah . Berdasarkan hasil survey, di Sei Bamban, Kotarih, Perbaungan dan Sei Rampah mumumnya lahan sawah milik petani itu sendiri dengan rata rata per petak adalah $400 \mathrm{M}^{2}$ dan $625 \mathrm{M}^{2}$.

\section{IV.3. Analisis Pendapatan Usaha Tani Padi Sawah.}

Analisis pendapatan usaha tani penting untuk diketahui guna memberikan gambaran mengenai keuntungan dari kegiatan usaha tani. Ananlisis pendapatan usaha tani meliputi 
analisis pendapatan atas biaya tunai dan analisis pendapatan biaya total. Pada komponen biaya, biaya yang dikeluarkan oleh petani sendiri dari biaya tunai dan biaya diperhitungkan. Biaya tunai terdiri dari biaya sarana produksi yang digunakan dalam usaha tani padi sawah seperti benih, pupuk, pestisida, sewa lahan, biaya angkut, biaya tenaga kerja luar keluarga dan biaya lain lain. Sedangkan komponen biaya yang diperhitungkan termasuk didalmnya adalah biaya tenaga kerja dalam keluarga.

\section{IV.4. Biaya produksi.}

Biaya produksi adalah semua biaya atau modal baik yang dibayar tunai maupun yang tidak dibayar tunai selama proses produksi berlangsung. Biaya tunai adalah biaya yang dikeluarkan secara langsung membeli sarana produksi (bibit, pupuk, pestisida dan lain sebagainya), alat alat pertanian dan upah tenaga kerja dari dalam dan luar keluarga. Biaya tidak tunai yaitu biaya yang tidak dikeluarkan secara langsung tetapi diperhitungkan, biaya tidak tunai dalam penelitian ini adalah upah tenaga kerja dalam keluarga dan sewa tanah sawah (Hermanto,1993).

Rata rata Biaya Usaha Tani Padi untuk luas lahan 0,308 ha di Kec. Sei Rampah.

\begin{tabular}{|l|l|l|r|r|r|}
\hline No & Nama Komponen & Satuan & Volume & Harga(Rp/Kg) & Total Harga (Rp) \\
\hline 1 & Sarana Produksi & & & & \\
& a.Benih & $\mathrm{Kg}$ & 7.7 & 7.500 & 58.000 \\
& b.Pupuk Urera & $\mathrm{Kg}$ & 49 & 2.000 & 98.000 \\
& c.Pupuk SP 36 & $\mathrm{Kg}$ & 16 & 2.400 & 24.000 \\
& d.Pupuk NPK & $\mathrm{Kg}$ & 39 & 3.200 & 125.000 \\
& e.Pestisida & $\mathrm{L}$ & 1 & 69.000 & 60.000 \\
& f. Insektisida & $\mathrm{L}$ & 0.5 & 75.000 & 36.000 \\
\hline 2 & Bahan : Goni/Karung & $\mathrm{Bh}$ & 25 & 2.000 & 50.000 \\
\hline \multicolumn{2}{|l|}{ Jumlah } & & & & $\mathbf{4 6 6 . 0 0 0}$ \\
\hline
\end{tabular}

Sumber : Data Primer (Diolah., 2019)

Berdasarkan table diatas, jika rata rata luas lahan padi sawah untuk setiuap responden 0.308 Ha, maka jumlah biaya produksi yang harus dikeluarkan dalam usaha tani budidaya padi sawah untuk satu musim tanam yang meliputi benih, pupuk urea, NPK, Sp-36, pestisida, insektisida, dam goni/karung adalah sebesar Rp. 466.000.

Sedangkan biaya tenaga kerja yang dikeluarkan adalah untuk kegiatan pengolahan tanah, penanaman, penyiangan, pemupukan, pengendalian hama dan penyakit, panen dan pasca panen adalah :

\begin{tabular}{|l|l|l|}
\hline No & Uraian & Jumlah biaya (Rp) \\
\hline 1. & Pengolahan Tanah & 459.000 \\
2. & Penanaman & 514.000 \\
3. & Penyiangan & 64.000 \\
4. & Pemupukan & 96.000 \\
5. & Pengendalian H\&P & 64.000 \\
6. & Pemanenan & 514.000 \\
7. & Pascapanen & 579.000 \\
\hline \multicolumn{2}{|l|}{ Jumlah } & $\mathbf{2 . 2 8 3 . 0 0 0}$ \\
\hline
\end{tabular}

Sumber : Petani Responden (2019) 
Berdasarkan table diatas,d ari beberapa keterangan hasil wawancara dengan reseponden bahwa total biaya tenaga kerja untuk kegiatan pengolahan lahan, penanaman, penyiangan, pemupukan, pengendalian $\mathrm{H} \& \mathrm{P}$, pemanenan dan pasca panen yang harus dikeluarkan oleh petani responden rata rata luas lahan0.308 Ha adalah sebesar Rp. 2.283.000.

\section{IV.5. Produksi dan Harga Jual.}

Jumlah produksi padi sawah yang dihasilkan oleh petani responden tergantung pada sistem penanaman dan pemeliharaaan yang intensif. Produksi adalah bentuk fisik terhadap padi sawah yang dihasilkan oleh petani dan juga merupakan salah satu faktor yang menentukan besar kecilnya laba/keuntungan yang akan diterima oleh para petani. Rata rata nilai produksi dan harga jual $/ \mathrm{kg}$ diterima petani responden padi sawah didaerah penelitian rata rata 11.395 ha dengan rata rata lahan untuk satu orang responden $3.078 \mathrm{M}^{2}(0.308 \mathrm{Ha})$ dan produksi GKP mencapaiu 5-6 ton /ha. Jumlah produksi padi sawah untuk satu orang responden rata rata mencapai $1.231 \mathrm{~kg}$ dengan harga jual rata rata mencapai $\mathrm{Rp}$. 4.135, sehingga diperoleh penerimaan rata rata sebesar Rp.5.097.000.

\section{IV.6. Pendapatan /Keuntungan.}

Usaha tani budidaya padi sawah didaerah penelitian yaitu Sei Bamban, Kotarih, perbaungan dan Sei Rampah terdapat keutungan yang bervariasi setelah dikurangi dengan biaya produksi dan biaya tenaga kerja yang dikeluarkan oleh petani responden adalah 0.308 ha - rata rata penerimaan sebesar Rp.5.097.000, rata rata biaya produksi adalah Rp.466.000, rata -rata biaya tenaga kerja sebesar Rp. 2.283.000. Setelah dikurangi biaya produksi dan tenaga kerja maka rata rata keuntungan yang diperoleh petani padi sawah diwilayah penelitian sebesar Rp. 2.749.000.

\section{IV.7. Analisa R/C Rasio.}

R/C Ratio menyatakan kelayakan suatu usaha tani apakah menguntungkan, balik modal atau tidak menguntungkan (rugi). Suatu usaha tani padi sawah dikatakan layak dan memberi manfaat apabila nilai $\mathrm{R} / \mathrm{C}$ ratio $>1$, semakin besar nilai keuntungan atas biaya maka semakin besar pula manfaat yang akan diperoleh dari usaha tersebut.

$$
\frac{R}{C} \text { Rasio }=\frac{T R}{T C}=\frac{5.097 .000}{2.749 .000}=1,8
$$

Artinya, setiap Rp. 1 yang dikeluarkan oleh petani untuk biaya usaha tani padi sawah maka akan menghasilkan keuntungan sebesar Rp. 1,8. Karena nilai R/C Ratio lebih besar dari 1 $(\mathrm{R} / \mathrm{C}>1)$ maka usaha tani padai sawah layak untuk dusahakan. Dengan demikian $\mathrm{n}$ bia penanaman padi dengan luasan yang semakin besar maka keuntungan yang diperoleh akan semakin besar.

\section{IV.8. Analisis Titik Pulang Pokok (BEP)}

Titik pulang pokok (Break event Point) adalah suatu titik output dimana kegiatan usaha tani padi sawah tidak mendapatkan laba/keuntungan dan pula tidak mengalami kerugian.

$$
\begin{gathered}
B E P \text { Harga }=\frac{T C}{Q}=\frac{2.749 .000}{1.231}=2.233 \\
B E P \text { Produksi }=\frac{2.749 .000}{4.135}=664
\end{gathered}
$$


Break Event Point atau titik impas pada usaha tani padi sawah di Kecamatan Sei Rampah Kabupaten Serdang Bedagai berdsarkan perhitungan menghasilkan BEP harga sebsear Rp 2.233 dan BEP Produksi $664 \mathrm{~kg}$. Artinya, bila petani reseponden di wilayah penelitian mengahsilkan produksi padi sawah sebesar $664 \mathrm{~kg}$ dengan harga jual Rp. 2.233 /Kg maka usaha tani padi sawah mengalami titik impas yakni tidak mengalami kerugian atau mendapatkan keuntungan.

\section{KESIMPULAN \& SARAN}

\section{V.1. Kesimpulan}

Adapun nkesimpulan yang dapat ditarik dari analisis yang telah dilakukan adalah sebagai berikut :

1. Rata rata luas lahan reseponden adalah $0.38 \mathrm{Ha}$, maka rata rata biaya produksi berupa saprodi pertanian yang harus dikeluarkan petani adalah Rp. 466000, rata rata biaya tenaga kerja sebesar Rp. 2.283.000 dan rata rata penerimaan adalah Rp. 7.646.000,-.

2. Rata rata penerimaan yang diperoleh petani padis awah di wilayah pennelitian sebsar Rp. 5.097.000 dan biaya produksi dan tenaga kerja sebesar Rp. 2.749.000 maka R/C ratio diperoleh sebesar sebesar 1.8. Artinya,s etiap Rp. 1 yang dikeluarkan oleh petani untuk biaya usaha tani padi sawah maka akan mengahsilkan keuntungan sebesar Rp. 1.8. Karena nilai $\mathrm{R} / \mathrm{C}$ ratio lebih bsesar dari pada $1(\mathrm{R} / \mathrm{C}>1)$ maka usaha tani padi sawah layak untuk diusahakan.

3. Break Event Point atau impas pada usaha tani padi sawah berdsarkan perhitungan menghasilkan BEP harga sebesar Rp. 2.233 dan BEP Produksi 664 kg. Artinya, bila petani reseponden di wilayah penelitian mengahsilkan produksi padi sawah sebesar $664 \mathrm{~kg}$ dengan harga jual Rp. $2.233 / \mathrm{kg}$ maka usaha tani padi sawah mengalamio titik impas, yakni tidak mengalami kerugian atau mendapatkan keuntungan.

\section{V.2. Saran.}

1. Diharapkan kepada para petani di wilayah Kecamatan Sei Rampah untuk terus meningkatkan pengetahuan, sikap dan keterampilan pada sektor pertanian terutama teknologi padi dan harus mampu menyerap inovasi inovasi yang menguntungkan yang disampaikan oleh instanasi instansi terkait dengan harapan mampu mempengaruhi produksi padi sawah dan peningkatan pendapatan pendapatan kearah yang lebih baik sehingga mampu mensejahterakan keluarga dan masyarakat.

\section{DAFTAR PUSTAKA}

Ananta, Aris, dkk, 1999. Ekonomi Sumber Daya Manusia, Jakarta : LDFE UI.

Dumairy, 2004. Matematika Terapan Untuk Bisnis dan Ekonomi, BPFE

Firdaus, Muhammad, 2008. Manajemen Agribisnis. Jakarta : PT. Bumi Aksara. 
Gasperz, V, 1999, Ekonomi Manajerial Pembuatan Keputusan Bisnis. Jakarta PT. Gramedia.

Hasrimi, Moettaqien, 2012. Analisis Pendapatan Petani Miskin dan Implikasi Kebijakan Pengentasannya di Kecamatan Perbaungan, kabupaten Serdang Bedagai. Tesis Magister Sains. Sekolah Pascasarjana Universitas Sumatera Utara.

Rahardi dan Hartono,2000. Agribisnis Peternakan.Jakarta : Penebar Swadaya.

Tarigan, Robinson, 2003. Ekonomi Regional Teori dan Aplikasi. Edisi Revisi Jakarta : Bumi Aksara. 